\title{
Occupational history, self reported chronic illness, and mortality: a follow up of 25586 Swedish men and women
}

\author{
Piroska Östlin
}

\begin{abstract}
Study objective-The aim of the study was to analyse the extent to which mortality can be predicted from data on self assessed chronic illness.

Design-The study used data obtained from ongoing surveys of living conditions conducted by Statistics Sweden using annual interviews of cohorts of about 8000 people.

Setting-The study was a population based survey of the whole of Sweden.

Participants-The analysis involved a group of 25586 respondents (males 12812 , females 12 774), aged 25-74 years, interviewed in 1977 and 1979-81.

Measurements and results-Mortality and occupational health selection were analysed in different occupational categories. The association between mortality and self reported morbidity was assessed. Level of physical strain at work was associated with mortality in men. Occupational health selection could be detected for men but not for women when mortality from all causes was investigated. Self assessment of health predicted mortality.
\end{abstract}

Conclusions-Subjective assessments of health through surveys are valuable as predictors of mortality for both men and women.

In the years 1977 and 1979-81 complete occupational histories were collected for 25586 men and women between 25 and 74 years of age, through personal interviews conducted by Statistics Sweden within the framework of the Annual Level of Living Surveys. At the same time, detailed accounts of the respondents' health status were also recorded. Linking the records on self reported chronic illness with death records gives a unique opportunity to study the association between subjective health ratings and mortality in the respondents.

The present study had two aims. The first was to investigate the extent to which mortality could be predicted from data on self reported chronic illness for the study population as a whole. It was assumed that respondents reporting any kind of chronic illness at the time of interview would experience higher mortality compared with the rest. The second aim was to study mortality for different occupational categories, defined according to physical strain at work. By considering occupational histories, it was to some extent possible to study the occupational health selection effect on mortality rates. Some methodological topics must, however, first be discussed.
USE OF "HARD" AND "SOFT" MORBIDITY

DAT A

"Hard" morbidity indicators such as clinical physician based measures or death are often regarded as more reliable than "soft" indicators such as subjective symptoms or self assessed health status. Mortality data are relatively easy to obtain and studies using these data can be done at a reasonable cost. Moreover, the immense literature describing the design of mortality studies and the sophisticated statistical methods available make the interpretation of mortality data easier. However, an increasing number of epidemiological studies have emphasised the crudeness of using mortality data exclusively in occupational and other studies. One major weakness of mortality data as a measure of ill health is that not all diseases are necessarily fatal. People no longer die, as they used to, from infectious diseases such as tuberculosis, scarlet fever, polio, etc. People now have a good chance of living for a long while, despite increased suffering and handicap from diseases of later life for which there are still no cures. The most typical and frequent chronic impairments of health, eg, heart and coronary artery disease, diseases of the musculoskeletal organs, chronic diseases of the bronchial tract and cancer, represent long term, cumulative disruptions of various mutually interdependent bodily functions and often involve several organs at once. Since the course of these diseases is often slow, they may coincide with other chronic diseases. Thus the state of ill health has become more and more complex, often with uncertain multicausal aetiology. Diseases of the musculoskeletal system for example are very common, especially among workers in physically demanding occupations, resulting in much suffering for the affected individuals. ${ }^{12}$ Workers are often forced to leave employment, either partly or entirely on account of musculoskeletal disorders, and this may lead to considerable changes in the circumstances of the diseased persons and their families. There are however, only a few deaths from diseases of the musculoskeletal system and connective tissues. Occupational mortality statistics therefore provide an incomplete picture of musculoskeletal health problems and their social and functional consequences.

A more detailed picture of an individual's health status can be obtained from the persons themselves. Data on ill health, life style, etc, can easily be collected from nation wide samples through health surveys. To what extent such self reported health reflects the interviewee's "true" health depends on a wide range of factors: how well the interviewee remembers life events, how 
inclined he is to report certain kinds of diseases, knowledge about illnesses, etc. However, self reported illness seems to be a valuable complement to mortality data, when a deeper knowledge of health differentials between occupational or other population groups is required.

OCCUPATIONAL EXPOSURE AND HEALTH For practical and other reasons, many investigations on work related disease are cross sectional. It is therefore important to discuss some of the problems typical of cross sectional study design, especially those which may severely affect validity. Occupational health selection is considered to be the most serious problem, and may mask real occupational health effects. One type of selection operates at the time of hirerecruitment of healthy individuals for employment, and the other type operates during the survival of healthy individuals in industrial employment. Both kinds of selection, which are also called "the healthy worker" effect, might cause an underestimation or an overestimation of occupational morbidity and mortality rates. ${ }^{3-12}$ An earlier study, based on the same data as this one, suggested that selection of workers with health problems out of physically heavy occupations into light occupations causes excess morbidity in the light category. ${ }^{13}$ In the present study, it was possible to examine whether the same kind of selection would also affect mortality rates.

\section{Methods}

STUDY POPULATION

The data utilised in the present study come from ongoing surveys on living conditions conducted by Statistics Sweden. Within the framework of these surveys about $\mathbf{8 0 0 0}$ people are interviewed annually about their living conditions, such as housing, family, social relations, health, leisure time activities, working environment, employment, etc. The present analyses consider a group of 25586 respondents interviewed in 1977 and in 1979-81, which included 12812 men and 12774 women 25-74 years of age. The development of these surveys as well as the quality issues involved are discussed elsewhere. ${ }^{14}$

\section{MEASURES OF ILL HEALTH}

Information on chronic illness was obtained during a personal interview. The respondent was first asked a general question about health status: "Do you suffer from any long term illness, after effects from an accident, disability or other ailment?". If the answer was "yes", the respondent was asked to report the kind of illness he or she was suffering from as accurately as possible. The interviewer probed the reported illness by questions such as "Could you explain that a little more?", "What did the doctor say it was", "What part of the body or organ system is affected?" Follow up questions by which it was possible to determine the amount of pain and suffering caused by the illness were also asked. In order to include symptom free conditions not covered by the previous question, the respondents were questioned concerning use of regular medication. The reported symptoms were coded according to the International Classification of Diseases, 8th revision (ICD).
MEASUREMENT OF MORTALITY

Mortality data were collected for the period from 1977 to 1986 from the Swedish National Death Registry. This register, kept by Statistics Sweden, comprise all deceased persons registered in the parish registers at the time of death, whether the death occurred in Sweden or abroad. The cause of death statistics are generally based on data from the medical death certificates. The causes of death are coded in accordance with the 1965 revision of the International Classification of Disease (ICD 8th revision). The linkage between the Living Condition Survey respondents and death records was performed via the so called civic number. This personal identity number, based on year, month and date of birth, a three digit serial number and one or two check digits, is unique for each individual in Sweden and provides a reliable identification system which makes computerised record linkage easy and safe.

MEASURES OF OCCUPATIONAL EXPOSURE In the years 1977 and $1979-81$ detailed recording of the occupational histories of the study population was completed. All jobs that lasted at least two years were recorded, together with detailed accounts of the respondents' current working conditions. The occupations were coded according to the Nordic Occupational Classification (NYK), which follows the recommendation of the three digit International Classifications (ISCO). The data on occupational history are naturally very complex and it is difficult to get a general view of them. There are over 300 occupational codes on the three digit level and each respondent could in principle have reported five different occupations. The possibilities for different groupings of the codes are many. For various reasons it might therefore be necessary to combine or join together occupational codes into larger categories. When classifying the level of exposure at work an Occupational Classification System proposed by Alfredsson and Theorell ${ }^{15}$ was used. Occupations in this system are classified by means of conditions in the working environment. For each demand (level of physical stress) the occupations are ranked by the proportion of employees reporting that demand at work. An index summarising eight different physical strains has been calculated for each occupation and two main exposure categories have been constructed separately for men and women. Those $50 \%$ of occupations with the highest index have been labelled "high exposure category" and the rest "low exposure category". The eight physical strains on which the index was based were selected by a factor analysis in which all factors had high score coefficients in the "physical work environment" dimension. These factors were: heavy lifts daily, repetitive and one sided working movements, unsuitable working postures, heavy shaking or vibration, perspiring daily from physical exertion, contact with dirt, deafening noise, and risk of exposure to accidents.

By classifying the occupations into heavy and light exposure categories according to the physical strain at work, occupational mobility between and within the categories could be studied. These groups are: 
-Stable workers in physically light occupations (workers with only one occupation during their lifetime).

- Stable workers in physically heavy occupations (workers with only one occupation during their lifetime).

-Movers within the light category

-Movers within the heavy category

-Movers from the heavy to the light category

- Movers from the light to the heavy category

-Movers with more than one transition between the light and heavy categories

\section{STATISTICAL METHODS}

The data were analysed using epidemiological programs developed by Rothman and Boice. ${ }^{16}$ The measure of association between self reported illness and mortality was the standardised rate ratio. ${ }^{17}$ Age adjusted mortality rate ratios were also calculated for different exposure categories, using Rothman's program "Estimation and testing for follow-up data with count or persontime denominators".

\section{Results}

Of the total study population of 25586 respondents, $1681(6.6 \%)$ died during the follow up period. The crude mortality rate was $8.4 \%$ among men and $4.7 \%$ among women (table I). More than half of the men $(53.7 \%)$ died from

Table I Number of interviews and number of deaths by sex

\begin{tabular}{|c|c|c|c|}
\hline & & $\begin{array}{l}\text { Number of } \\
\text { persons } \\
\text { interviewed, } \\
1977-1981\end{array}$ & $\begin{array}{l}\text { Number of } \\
\text { persons } \\
\text { deceased, } \\
\text { 1977-1986 }\end{array}$ \\
\hline Men & $\begin{array}{l}\mathbf{n} \\
\%\end{array}$ & $\begin{array}{l}12812 \\
(100)\end{array}$ & $\begin{array}{l}1078 \\
(8 \cdot 4)\end{array}$ \\
\hline Women & $\begin{array}{l}\mathbf{n} \\
\%\end{array}$ & $\begin{array}{l}12774 \\
(100)\end{array}$ & $\begin{array}{r}603 \\
(4 \cdot 7)\end{array}$ \\
\hline Total & $\begin{array}{l}\mathbf{n} \\
\%\end{array}$ & $\begin{array}{l}25866 \\
(100)\end{array}$ & $\begin{array}{l}1681 \\
(6 \cdot 6)\end{array}$ \\
\hline
\end{tabular}

diseases of the circulatory organs. Among women, diseases of the circulatory organs were also the most frequent cause of death $(45.4 \%)$. The second main cause of death for men and women was neoplasms $(26 \cdot 5,36 \cdot 5 \%)$, followed by injuries due to external violence $(7 \cdot 2,5 \cdot 3 \%)$ and diseases of the respiratory organs ( $4.5 \%$ for both sexes) (table II).

Table III gives age specific mortality rates and standardised rate ratios for both sexes. The computation of mortality rates and rate ratios was completed separately for those who at the time of interview reported at least one long term illness, and for those who did not. The crude mortality

Table II Distribution of deaths by cause for men and women, 1977-1986

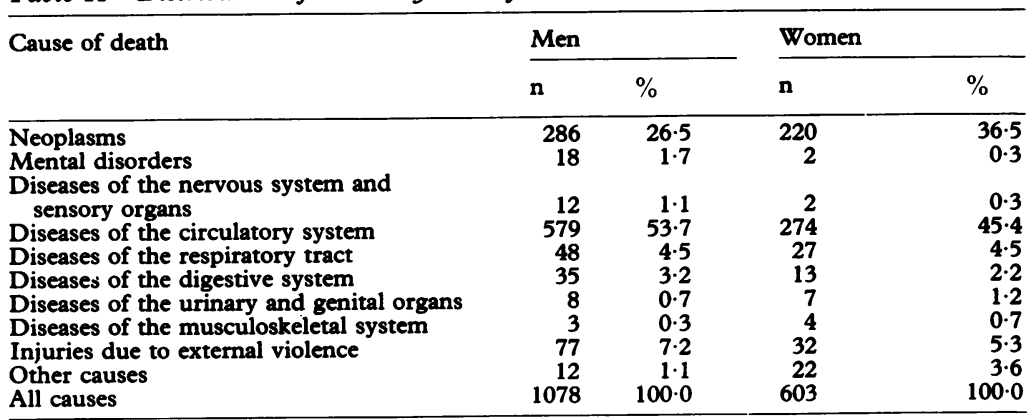

Table III Age specific mortality rate per 100 (all causes) for men and women by self reported long term illness, 1977-1986

\begin{tabular}{|c|c|c|c|c|}
\hline \multirow{3}{*}{ Age (years) } & \multicolumn{4}{|c|}{ Self reported long term illness } \\
\hline & \multicolumn{2}{|c|}{ No } & \multicolumn{2}{|c|}{ Yes } \\
\hline & Rate & $\mathbf{n}$ & Rate & $\mathbf{n}$ \\
\hline $\begin{array}{l}\text { Men } \\
25-34 \\
35-44 \\
45-54 \\
55-64 \\
65+\end{array}$ & $\begin{array}{r}0.6 \\
1.2 \\
2.9 \\
6.9 \\
19.3\end{array}$ & $\begin{array}{r}2479 \\
1939 \\
1395 \\
1052 \\
679\end{array}$ & $\begin{array}{r}0.9 \\
1.8 \\
8.8 \\
17.4 \\
32.5\end{array}$ & $\begin{array}{r}747 \\
773 \\
923 \\
1475 \\
1350\end{array}$ \\
\hline $\begin{array}{l}\text { Crude rate } \\
\text { SRR }\end{array}$ & $\begin{array}{l}3.7 \\
1.0\end{array}$ & 7544 & $\begin{array}{l}15 \cdot 1 \\
2 \cdot 3 \ddagger\end{array}$ & 5268 \\
\hline $\begin{array}{l}\text { Women } \\
25-34 \\
35-44 \\
45-54 \\
55-64 \\
65+\end{array}$ & $\begin{array}{r}0.6 \\
0.7 \\
1.4 \\
3.8 \\
10.3\end{array}$ & $\begin{array}{r}2367 \\
1929 \\
1330 \\
963 \\
633\end{array}$ & $\begin{array}{r}0.7 \\
1.6 \\
2.4 \\
9.0 \\
18.7\end{array}$ & $\begin{array}{r}699 \\
768 \\
1075 \\
1547 \\
1463\end{array}$ \\
\hline $\begin{array}{l}\text { Crude rate } \\
\text { SRR }\end{array}$ & $\begin{array}{l}2.0 \\
1.0\end{array}$ & 7223 & $\begin{array}{l}8 \cdot 2 \\
2 \cdot 1 \ddagger\end{array}$ & 5551 \\
\hline
\end{tabular}

$\mathrm{SRR}=$ Standardised rate ratio

$\neq \mathrm{p}<0.001$

rate was more than four times as high among both male and female respondents who had reported long term illness at interview. The standardised rate ratios of 2.3 for men and $2 \cdot 1$ for women were highly significant $(p<0.001)$.

In tables IV and $V$, mortality in different occupational categories is shown, defined according to the physical demands at work. For men who had left physically demanding occupations and moved to physically light occupations, a significantly higher standardised rate ratio of 1.21 was obtained, using stable workers at the light level as the reference category. Workers in heavy occupations also had significantly higher mortality compared with stable workers in light occupations. However, mortality differences among women in different occupational categories were relatively small.

Tables VI and VII show the distribution of deaths by the most frequent causes in different occupational categories. According to the results in table VI, mortality from circulatory diseases and from diseases of the respiratory tract was higher among male workers in physically demanding occupations. Mortality from injuries due to external violence was considerably higher among workers in light occupations. Death rates from neoplasms were about the same in the main exposure categories.

Mortality patterns among women in different exposure categories were quite different from those among men. Women in physically light occupations died more often from neoplasms than women with heavy work. The latter group had, on the other hand, higher mortality from diseases of the circulatory organs. Deaths from injuries due to external violence and from respiratory diseases were more common among women in light work.

\section{Discussion}

The first question in the present study concerned the relationship between "soft" and "hard" morbidity data. The analysis showed a significant association between self reported health problems and increased risk of death for both men and women. Subjective assessments of health have been considered to be good predictors of 
Table IV Number of deaths, and person years among different

occupational categories. Men in Sweden 1977-

1986. Crude and age

adjusted rate ratios with $90 \%$ confidence intervals (CI) for the adjusted ratios

Table $V$ Number of deaths, and person years among different

occupational categories.

Women in Sweden 1977-

1986. Crude and age

adjusted rate ratios with $90 \%$ confidence intervals (CI) for the adjusted ratios.

Table VI Distribution of deaths by selected causes in different occupational categories. Men in Sweden 1977-1986
Table VII Distribution of deaths by selected causes in different occupational categories. Women in Sweden 1977-1986

\begin{tabular}{|c|c|c|c|c|c|}
\hline Occupational history & Deaths & Person years & Crude RR & $\begin{array}{l}\text { Age adjusted } \\
\text { RR }\end{array}$ & $90^{\circ}{ }_{\mathrm{o}} \mathrm{CI}$ \\
\hline $\begin{array}{l}\text { Light work: } \\
\text { Stable workers } \\
\text { Movers within the category } \\
\text { Movers from the heavy category }\end{array}$ & $\begin{array}{r}104 \\
78 \\
159\end{array}$ & $\begin{array}{r}16085 \\
7537 \\
13167\end{array}$ & $\begin{array}{l}1.00 \\
1.67 \\
1.97\end{array}$ & $\begin{array}{l}1 \cdot 00 \\
1 \cdot 19 \\
1 \cdot 21^{\star}\end{array}$ & $\begin{array}{l}\text { Reference category } \\
0.93-1.52 \\
1.08-1.48\end{array}$ \\
\hline $\begin{array}{l}\text { Heavy work: } \\
\text { Stable workers } \\
\text { Movers within the category } \\
\text { Movers from the light category }\end{array}$ & $\begin{array}{r}306 \\
363 \\
25\end{array}$ & $\begin{array}{r}19852 \\
23529 \\
2834\end{array}$ & $\begin{array}{l}2 \cdot 48 \\
2 \cdot 48 \\
1 \cdot 46\end{array}$ & $\begin{array}{l}1.55 \ddagger \\
1.31 \dagger \\
1.23\end{array}$ & $\begin{array}{l}1 \cdot 28-1 \cdot 87 \\
1.08-1.57 \\
0.87-1 \cdot 75\end{array}$ \\
\hline $\begin{array}{l}\text { More than one transition between light and } \\
\text { heavy work }\end{array}$ & 43 & 3395 & 2.02 & $1 \cdot 16$ & $0.86-1.56$ \\
\hline \multicolumn{6}{|l|}{${ }^{\star} \mathrm{p}<0.1 ; \dagger \mathrm{p}<0.01 ; \mp \mathrm{p}<0.001$} \\
\hline Occupational history & Deaths & Person years & Crude RR & $\begin{array}{l}\text { Age adjusted } \\
\text { RR }\end{array}$ & $90 \% \mathrm{CI}$ \\
\hline $\begin{array}{l}\text { Light work: } \\
\text { Stable workers } \\
\text { Movers within the category } \\
\text { Movers from the heavy category }\end{array}$ & $\begin{array}{l}90 \\
24 \\
32\end{array}$ & $\begin{array}{r}24516 \\
7034 \\
7961\end{array}$ & $\begin{array}{l}1.00 \\
0.93 \\
1 \cdot 10\end{array}$ & $\begin{array}{l}1.00 \\
0.98 \\
0.77\end{array}$ & $\begin{array}{l}\text { Reference category } \\
0 \cdot 67-1 \cdot 44 \\
0 \cdot 54-1.08\end{array}$ \\
\hline $\begin{array}{l}\text { Heavy work: } \\
\text { Stable workers } \\
\text { Movers within the category } \\
\text { Movers from the light category }\end{array}$ & $\begin{array}{r}251 \\
174 \\
22\end{array}$ & $\begin{array}{r}23226 \\
20298 \\
5053\end{array}$ & $\begin{array}{l}2 \cdot 94 \\
2 \cdot 31 \\
1 \cdot 19\end{array}$ & $\begin{array}{l}1.17 \\
1.06 \\
0.97\end{array}$ & $\begin{array}{l}0.95-1.43 \\
0.85-1.31 \\
0.65-1.44\end{array}$ \\
\hline $\begin{array}{l}\text { More than one transition between light and } \\
\text { heavy work }\end{array}$ & 10 & 2705 & 1.07 & 0.71 & $0.41-1 \cdot 22$ \\
\hline
\end{tabular}

\begin{tabular}{|c|c|c|c|c|c|c|}
\hline & \multicolumn{6}{|c|}{ Cause of death } \\
\hline & $\begin{array}{l}\text { Neoplasms } \\
\% \\
(\mathbf{n})\end{array}$ & $\begin{array}{l}\text { Circulatory } \\
\text { disease } \\
\% \\
\text { (n) }\end{array}$ & $\begin{array}{l}\text { Respiratory } \\
\text { disease } \\
0 \\
\text { (n) }\end{array}$ & $\begin{array}{l}\text { Injuries } \\
\% \\
\text { (n) }\end{array}$ & $\begin{array}{l}\text { Other } \\
\text { causes } \\
0 \\
\text { (n) }\end{array}$ & $\begin{array}{l}\text { All } \\
\text { causes } \\
\text { o } \\
\text { (n) }\end{array}$ \\
\hline \multicolumn{7}{|l|}{ Light work: } \\
\hline $\begin{array}{l}\text { Stable } \\
\text { Movers in the category } \\
\text { Movers from heavy category } \\
\text { All workers with light work }\end{array}$ & $\begin{array}{l}31 \cdot 7 \\
(33) \\
31 \cdot 2 \\
(24) \\
27 \cdot 0 \\
(43) \\
29 \cdot 4 \\
(100)\end{array}$ & $\begin{array}{l}48 \cdot 2 \\
(50) \\
39 \cdot 0 \\
(30) \\
47 \cdot 2 \\
(75) \\
45 \cdot 6 \\
(155)\end{array}$ & $\begin{array}{l}3 \cdot 8 \\
(4) \\
2 \cdot 6 \\
(2) \\
3 \cdot 1 \\
(5) \\
3 \cdot 2 \\
(11)\end{array}$ & $\begin{array}{c}9.6 \\
(10) \\
13.0 \\
(10) \\
10.1 \\
(16) \\
10.6 \\
(36)\end{array}$ & $\begin{array}{l}6.7 \\
(7) \\
14.2 \\
(11) \\
12.6 \\
(20) \\
11.2 \\
(38)\end{array}$ & $\begin{array}{l}100 \\
(104) \\
100 \\
(77) \\
100 \\
(159) \\
100 \\
(340)\end{array}$ \\
\hline \multicolumn{7}{|l|}{ Heavy work: } \\
\hline $\begin{array}{l}\text { Stable } \\
\text { Movers in the category } \\
\text { Movers from light category } \\
\text { All workers with heavy work }\end{array}$ & $\begin{array}{l}22.9 \\
(70) \\
27.6 \\
(101) \\
20.0 \\
(5) \\
25.2 \\
(176)\end{array}$ & $\begin{array}{l}57 \cdot 5 \\
(176) \\
5 \mathrm{k} 6 \cdot 5 \\
(203) \\
60 \cdot 0 \\
(15) \\
56 \cdot 3 \\
(394)\end{array}$ & $\begin{array}{l}5 \cdot 6 \\
(17) \\
5 \cdot 1 \\
(19) \\
- \\
\overline{5} \cdot 1 \\
(36)\end{array}$ & $\begin{array}{c}6 \cdot 8 \\
(21) \\
4.1 \\
(15) \\
8.0 \\
(2) \\
5.3 \\
(38)\end{array}$ & $\begin{array}{c}7 \cdot 2 \\
(22) \\
6 \cdot 7 \\
(25) \\
12 \cdot 0 \\
(3) \\
8 \cdot 1 \\
(57)\end{array}$ & $\begin{array}{l}100 \\
(306) \\
100 \\
(363) \\
100 \\
(25) \\
100 \\
(694)\end{array}$ \\
\hline More than one transition between the levels & $\begin{array}{l}20 \cdot 9 \\
(9)\end{array}$ & $\begin{array}{l}67 \cdot 4 \\
(29)\end{array}$ & $\begin{array}{l}2 \cdot 3 \\
(1)\end{array}$ & $\begin{array}{c}4 \cdot 7 \\
(2)\end{array}$ & $\begin{array}{l}4 \cdot 7 \\
(2)\end{array}$ & $\begin{array}{l}100 \\
(43)\end{array}$ \\
\hline
\end{tabular}

\begin{tabular}{|c|c|c|c|c|c|c|}
\hline & \multicolumn{6}{|c|}{ Cause of death } \\
\hline & $\begin{array}{l}\text { Neoplasms } \\
\% \\
\text { (n) } \\
\end{array}$ & $\begin{array}{l}\text { Circulatory } \\
\text { disease } \\
\% \\
\text { (n) } \\
\end{array}$ & $\begin{array}{l}\text { Respiratory } \\
\text { disease } \\
\% \\
\text { (n) } \\
\end{array}$ & $\begin{array}{l}\text { Injuries } \\
\% \\
\text { (n) }\end{array}$ & $\begin{array}{l}\text { Other } \\
\text { causes } \\
\text { o } \\
(\mathbf{n}) \\
\end{array}$ & $\begin{array}{l}\text { All } \\
\text { causes } \\
\text { o } \\
\text { (n) } \\
\end{array}$ \\
\hline \multicolumn{7}{|l|}{ Light work: } \\
\hline $\begin{array}{l}\text { Stable } \\
\text { Movers in the category } \\
\text { Movers from heavy category } \\
\text { All workers with light work }\end{array}$ & $\begin{array}{l}48.9 \\
(44) \\
41.7 \\
(10) \\
37.5 \\
(12) \\
45.2 \\
(66)\end{array}$ & $\begin{array}{l}31 \cdot 1 \\
(28) \\
29 \cdot 2 \\
(7) \\
37 \cdot 5 \\
(12) \\
32 \cdot 2 \\
(47)\end{array}$ & $\begin{array}{l}5 \cdot 6 \\
(5) \\
16 \cdot 6 \\
(4) \\
- \\
- \\
6 \cdot 2 \\
(9)\end{array}$ & $\begin{array}{c}8 \cdot 9 \\
(8) \\
4 \cdot 2 \\
(1) \\
12.5 \\
(4) \\
8.9 \\
(13)\end{array}$ & $\begin{array}{l}5 \cdot 5 \\
(5) \\
8 \cdot 3 \\
(2) \\
12 \cdot 5 \\
(4) \\
7 \cdot 5 \\
(11)\end{array}$ & $\begin{array}{l}100 \\
(90) \\
100 \\
(24) \\
100 \\
(32) \\
100 \\
(146)\end{array}$ \\
\hline \multicolumn{7}{|l|}{ Heavy work: } \\
\hline $\begin{array}{l}\text { Stable } \\
\text { Movers in the category } \\
\text { Movers from light category } \\
\text { All workers with heavy work }\end{array}$ & $\begin{array}{l}27.9 \\
(70) \\
42.5 \\
(74) \\
27 \cdot 3 \\
(6) \\
33.6 \\
(150)\end{array}$ & $\begin{array}{l}55 \cdot 8 \\
(140) \\
43 \cdot 1 \\
(75) \\
45 \cdot 5 \\
(10) \\
50 \cdot 3 \\
(225)\end{array}$ & $\begin{array}{c}3 \cdot 6 \\
(9) \\
5 \cdot 2 \\
(9) \\
- \\
- \\
4 \cdot 0 \\
(18)\end{array}$ & $\begin{array}{c}4 \cdot 7 \\
(12) \\
2 \cdot 3 \\
(4) \\
9 \cdot 1 \\
(2) \\
4 \cdot 0 \\
(18)\end{array}$ & $\begin{array}{c}8 \cdot 0 \\
(20) \\
6.9 \\
(12) \\
18 \cdot 1 \\
(4) \\
8 \cdot 1 \\
(36)\end{array}$ & $\begin{array}{l}100 \\
(251) \\
100 \\
(174) \\
100 \\
(22) \\
100 \\
(447)\end{array}$ \\
\hline More than one transition between the levels & $\begin{array}{l}40 \cdot 0 \\
(4)\end{array}$ & $\begin{array}{l}30 \cdot 0 \\
(3)\end{array}$ & $\overline{-}$ & $\begin{array}{l}10 \cdot 0 \\
\text { (1) }\end{array}$ & $\begin{array}{l}20 \cdot 0 \\
(2)\end{array}$ & $\begin{array}{l}100 \\
(10)\end{array}$ \\
\hline
\end{tabular}

mortality. The results are consistent with those age adjusted relative risk for mortality from all found using the 1965 Human Population causes for those who perceived their health as Laboratory survey in Alemeda County, poor as compared to excellent was considerably California ${ }^{18}$ : Kaplan and Camacho found that the higher. This association persisted in multiple 
logistic analyses with controls for age, sex, education, income, etc. A study by Mossey and Shapiro also provides strong support for the association between perceived health and mortality in a cohort of persons over 65 years of age. ${ }^{19}$ Similar results were also obtained by Hunt et $a{ }^{2021}$ Blaxter, 22 Brennan and Clare, ${ }^{23}$ Forster, ${ }^{24}$ and Mägi et al. ${ }^{25}$

The main conclusion from the results of the present and other similar studies is that subjective assessments of health have a value as predictors of mortality. Moreover, the strong relationship between self reported illness and mortality implies that subjective measures of health through surveys are valuable tools of risk appraisal in different populations.

The second question posed by the study concerned mortality differentials between occupational categories, where occupational histories were taken into consideration. The results indicated excess mortality in physically heavy occupations for men, but not for women. Risk of death was significantly higher for workers who had left physically demanding work for lighter work compared to those who always had light work. These results indicated "negative health selection" into the category of light occupations, causing an excess mortality there. A similar observation was made for the same study population in an earlier study on the occurrence of long term illness. ${ }^{13}$ The selection effect in that study was even more obvious, especially for musculoskeletal diseases. Mortality from musculoskeletal disorders is very low, however, and while the few deaths do not allow analysis of selection effects on musculoskeletal mortality rates, the methodological problems of over- and underestimation of risk of death in different occupations will still remain. Selection effects on morbidity rates could also be shown for women in the study mentioned above, ${ }^{13}$ though selection effects on mortality from all causes could not be shown. This might be due to the fact that women in general hold physically less demanding jobs compared to men and consequently are less likely to have moved into other occupations because of health problems. Furthermore, the weaker association in women between physical strain at work and mortality at the crude level (ie, mortality from all causes) might be explained by lower average exposure time at work (ie, a higher proportion of part time workers among women than among men). However, mortality from, for example, neoplasms and circulatory diseases is rather different in the groups making up the same exposure categories: eg, women who moved from heavy to light occupations experienced lower death rates from neoplasms than women who had always worked at the light level-a result which might lead to underestimation of cancer risks in light occupations, especially in data gathered cross sectionally. Death from diseases of the circulatory system, on the other hand, seemed to be much more common among stable workers at the heavy level ( $55.8 \%$ of all deaths in this group) than among workers who moved from the light level to the heavy level $(45.5 \%)$. Thus there might be a risk of underestimating risk factors important for mortality from diseases of the circulatory system.

Conclusions from the second part of this study are that there are clear differences in mortality between physically heavy and physically light occupations in men. Health related selection effects could be detected for men, but not for women, when mortality from all causes was investigated. When more specific causes of death were investigated, selection effects could also be detected for women.

This study was supported in part by grants from the Swedish Work Environment Fund, and in part by Statistics Sweden. We thank Mats Thorslund, assistant professor, Department of Social Medicine, University of Uppsala, for his valuable contributions.

1 Anderson JAD. Shoulder pain and tension neck and their relation to work. Scand $\%$ Work Environ Health 1984; 10 : relation

2 Troup IDG. Causes, prediction and prevention of back pain. Scand F Work Environ Health 1984; 10: 419-28.

3 Vinni K, Hakama M. Healthy worker effect in the total Finnish population. Br Y Ind Med 1980; 37: 180-4.

4 Olsen J. Some methodological problems encountered in occupational health research. Scand $Y$ Soc Med 1981; 9 . 19-24.

5 Fox AJ, Goldblatt PO, Adelstein AM. Selection and mortality differentials. 'I Epidemiol Community Health 1982; 36: 69-79.

6 Koskela R-S. Occupational mortality and morbidity in relation to selective turnover. Scand Y Work Environ Health 1983; 8 (suppl 1): 34-9.

7 Ostlin P, Thorslund M. Problems with cross-sectional data in research on working environment and health. Scand $\mathcal{Y}$ Soc Med 1988; 16: 139-43.

8 Sterling DT, Weinkam JJ. The "healthy worker effect" on morbidity rates. ₹ Occup Med 1985; 37: 477-82.

morbidity rates. $F$ Occup Med $1985 ; 37: 477-82$.
Page FW. Mortality and morbidity selection effects among Page FW. Mortality and morbidity selection

10 Wilcosky T, Wing S. The healthy worker effect. Selection of workers and work forces. Scand $\mathcal{Y}$ Work Environ Health 1987; 13: 70-2.

11 Carpenter ML. Some observations on the healthy worker effect. Br Y Ind Med 1987; 44: 289-91.

12 Weed DL, Tyroler HA, Shy C. The healthy worker effect in actively working communications workers. $\mathcal{f}$ Occup $\mathrm{Med}$ 1987; 29: 335-9.

13 Ostlin P. Negative health selection into physically light occupations. I Epidemiol Community Health 1988; 42: $152-6$.

14 Thorslund M, Warneryd B. Methodological research in the Swedish surveys of living conditions. Problems of measurement and data collection. Social Indicators Research 1985; 1: 77-95.

15 Alfedeson I Theorell T. Slutrapport an projekt Dn 81/0744. Psykosocial arbetsmiljö och hjärtinfarktrisk. 81/0744. Psykosocial arbetsmiljo och hjartinfarktrisk. (Psychosocial working environment and myocardial infarction ris

16 Rothman K, Boice D. Epidemiologic analysis with a programmable calculator. DREW publication No. (NIH) 79-1649. Washington, DC: Government Printing Office, 1979.

17 Miettinen O. Simple interval estimation of risk ratio. $\mathrm{Am} \mathfrak{Y}$ Epidemiol 1974; 100: 515-6.

18 Kaplan GA, Camacho T. Perceived health and mortality: a nine-year follow-up of the Human Population Laboratory cohort. Am $₹$ Epidemiol 1983; 117: 292-304.

19 Mossey JM, Shapiro E. Self-rated health: a predictor of mortality among the elderly. Am Y Public Health 1982; 72 $800-8$.

20 Hunt SM, McKenna SP, McEwen J, Backett EM, Williams J, Papp E. A quantitative approach to perceived health 1980; 34: 281-6.

21 Hunt SM, McEwen J, McKenna SP. Perceived health: age and sex comparisons in a community. $f$ Epidemiol and sex comparisons in a comm

22 Blaxter $M$. Self-definition of health status and consultation rates in primary care. $Q \mathcal{O}$ Social Affairs 1985; 1 : 131.

23 rates in primary care. $Q \mathcal{F}$ Social Affairs $1985 ; 1$ : 131 . Brennan ME, Clare PH. The relationship between mortality and two indicators of mort

24 Forster DP. Mortality, morbidity and resource allocation. Lancet 1977; i:997.

25 Magi M, Allander E, Bjelle A, Ragnarsson A. Rheumatic disorders in a health survey: how valid and reliable are the reports? Scand $\mathcal{S}$ Soc Med 1984; 12: 141-6. 